О.М. Балакірєва, канд. соціол. наук

O.M. Balakireva, Candidate of Sociol. Sci.

Д.А. Дмитрук

\title{
D.A. Dmytruk
}

\section{ПОЛІТИЧНА СИТУАЦІЯ У ДЗЕРКАЛІ ГРОМАДСЬКӦ̈ ДУМКИ: ЛИПЕНЬ 2007 р.}

Abstract. The material is based on the results of a monitoring of the public opinion which was executed jointly by the Ukrainian Institute of Social Research and the center "Social monitoring" (July 2007).

Для підготовки матеріалу використано результати моніторингу громадської думки, що проводиться спільно Українським інститутом соціальних досліджень ім. Олександра Яременка та Центром “Соціальний моніторинг”.

Тип дослідження: репрезентативне опитування населення методом індивідуального інтерв'ю (“віч-на-віч”) за місием проживання респондента.

Опитування проводилося з 10 по 18 липня 2007 року.

Географія проведення: загальнонаціональне, в усіх областях України, АР Крим, містах Києві та Севастополі. Опитування проведено у 132 населених пунктах України: 67 містах та 65 селах. Всъого опитано 2014 респондентів віком від 18 років і старие. Стандартні відхилення при достовірних 95\% і співвідношенні змінних від 0,1 : 0,9 до 0,5 : 0,5 становлять 1,34-2,24 відсотка. Рівень досягнення респондентів $-\mathbf{7 1 , 3 \%}$.

\section{Основні висновки}

- Переважна більшість опитаних (80\%) вбачають що зараз мають місце порушення Конституції з боку певних державних інституцій.

- За порушника Конституції респонденти частіше вважають Президента (34\%), ніж Верховну Раду (28,5\%) чи Уряд (11\%).

- Більше чверті опитаних $(28,5 \%)$ вбачають загрозу для себе та своєї родини у тому, що порушується Конституція.

- $\quad 41 \%$ опитаних вказали, що порушення Конституції загрожує цілісності та суверенітету країни.

- 44\% вважають можливими масові виступи на захист своїх прав, а 31\% можуть особисто взяти в них участь.

- $\quad$ 44,5\% респондентів не підтримують ідеї проведення дострокових виборів.

- У суспільстві продовжує переважати протистояння щодо вступу до НАТО (57\%), а основним зовнішньополітичним пріоритетом вважається зближення з Росією. Загалом, виключно проросійський вектор підтримують 41-43\% опитаних. 


\section{МОНТТОРИНГ ГРОМАДСЬКОї ДУМКИ}

- Третина населення (33,5\%) вважає, що необхідно залишити без змін ситуацію із російською мовою, чверть $(26,6 \%)$ - що російській мові необхідно надати статус другої державної; ще майже чверть (25\%) пропонує зробити російську мову другою офіційною мовою в тих областях, де більшість населення цього бажає.

- Відповідно до результатів проведеного дослідження, найбільшою довірою населення зараз користуються такі політичні об’єднання: Партія регіонів (довіряють партії 43\%), БЮТ (34\%), блоки "Наша Україна" (31\%) та "Народна самооборона" (29\%), Комуністична партія України (26\%). Цим політичним силам довіряє понад чверть населення.

- Найвищий рівень неприйняття можна побачити щодо Блоку Ю. Тимошенко (43\%). На другому місці у негативному рейтингу Партія регіонів (32\%), Блок “НУ” (32\%) та КПУ (31\%).

- За більш ніж два місяці до проголошеної дати дострокових виборів майже 80\% опитаних збирається приходити на виборчі дільниці. Явку виборців можна прогнозувати на рівні 70-75\%.

- Основними проблемами, що хвилюють населення, залишаються питання надання доброякісних медичних послуг, забезпечення робочими місцями та зростання цін.

\section{$>$ Оцінки політичної ситуації \\ о Ставлення населення до Конституції та її оцінки}

Порушниками Конституції респонденти частіше зазначають Президента (34\%) та Верховну Раду (28,5\%). Проте різницю за цими варіантами відповіді не можна інтерпретувати як перевагу однієї позиції над іншою. Скоріше, така ситуація ще раз засвідчує розкол суспільства на два табори. Лише 7\% вважають, що порушень Конституції не було.

Таблиця 1

Розподіл відповідей на запитання: “Як Ви вважаєте, чи мають на даний час місце порушення Конституціі з боку певних державних інституцій?”, \%

(Сума відповідей перевищує 100\% тому, що респондент міг вказати більше одного варіанта відповіді)

\begin{tabular}{|c|c|c|}
\hline $\begin{array}{l}\text { Так, я вважаю, що Президегт України незакониим розпуском Верховної } \\
\text { Ради Украйни та іншими своїми діями порушус Конституціо держави }\end{array}$ & 34,1 & \\
\hline Так, я вважаю, що Верховна Рада України порушила Конституцію держави & 28,5 & 79,9 \\
\hline Так, я вважаю що Уряд порушуе Конституцію держави & 11,1 & \\
\hline Так, я вважаю що опозиція порушуе Конституцію держави & 6,2 & \\
\hline $\begin{array}{l}\text { Ні, я вважаю, що з боку будь-яाких державних інституцій порушень } \\
\text { Конституції останнім часом не було }\end{array}$ & \multicolumn{2}{|c|}{7,2} \\
\hline Важкко відповісти & \multicolumn{2}{|c|}{19,1} \\
\hline
\end{tabular}


Більше чверті опитаних вбачають загрозу для себе та своєї родини у тому, що порушується Конституція.

Таблиця 2

Розподіл відповідей на запитання: “Як Ви вважаєте, чи загрожують взагалі можливі або реальні порушення Конституції України з боку певних державних інституцій Вашій особистій безпеці та безпеці Вашої родини?", \%

\begin{tabular}{|l|c|}
\hline $\begin{array}{l}\text { Так, я відчуваю загрозу своїй особистій безпеці та безпеці моєї родини через } \\
\text { порушення Конституції }\end{array}$ & 28,5 \\
\hline $\begin{array}{l}\text { Нi, я вважаю, що такі проблеми особисто моїй безпеці та безпеці мосї родини не } \\
\text { загрожують }\end{array}$ & 56,3 \\
\hline Важкко відповісти & $\mathbf{1 5 , 2}$ \\
\hline
\end{tabular}

Оцінюючи загрози, які спричиняються порушеннями Конституції, опитані були більш свідомі і вже більша їх частка (41\%) вказала, що відчуває загрозу цілісності та суверенітету країни. Відповідь на це запитання поділяє населення на два протилежних та практично рівновеликих табори (крім п’ятої частини тих, хто не визначився).

Таблиця 3

Розподіл відповідей на запитання: “Як Ви вважаєте, чи загрожують взагалі можливі або реальні порушення Конституції України з боку певних державних інституцій суверенітету та цілісності країни?”, \%

\begin{tabular}{|l|c|}
\hline Так, я відчуваю таку загрозу & 40,8 \\
\hline $\begin{array}{l}\text { Ні, я вважаю, що до таких наслідків порушення Конституції на } \\
\text { даний час призвести не можуть }\end{array}$ & 39,1 \\
\hline Важко відповісти & 20,0 \\
\hline
\end{tabular}

о Протестний потенціал населення: оцінки вірогідності масових виступів та активності населення

Проведене опитування засвідчило доволі високий рівень протестного потенціалу: 44,3\% опитаних вважають можливими масові акції, а 31,1\% припускають свою участь в них. Звісно, більшість із тих, хто сказав, що візьме участь, насправді навряд чи вдасться до цього, але отриманий показник засвідчує високий рівень тривожності населення та його налаштованість щодо участі в політичному житті країни.

Таблиця 4

Розподіл відповідей на запитання: “Як Ви вважаєте, наскільки можливі масові виступи населення на захист своїх прав у Вашому місті/районі, регіоні?”, \%

\begin{tabular}{|l|c|c|}
\hline Так & 18,0 & \multirow{2}{*}{44,3} \\
\hline Швидше, так & 26,3 & \\
\cline { 1 - 2 } Швидше, ні & 25,1 & \multirow{2}{*}{46,5} \\
\hline Важко відповісти & 21,4 & \\
\hline
\end{tabular}


Розподіл відповідей на запитання: “Якщо такі мітинги, демонстрації протесту відбудуться,

Ви особисто будете в них брати участь чи ні?”, \%

\begin{tabular}{|l|c|c|}
\hline Так & 18,0 & \multirow{2}{*}{44,3} \\
\hline Швидше, так & 26,3 & \\
\cline { 1 - 2 } Швидше, ні & 25,1 & \multirow{2}{*}{46,5} \\
\hline Ні & 21,4 & \multicolumn{2}{|c|}{9,2} \\
\hline Важко відповісти & \multicolumn{2}{|c|}{} \\
\hline
\end{tabular}

о Ставлення населення до ідеї розпуску діючої Верховної Ради та проведення дострокових парламентських виборів

На сьогоднішній день ставлення до указів Президента про розпуск Верховної Ради фактично повністю віддзеркалює електоральні симпатії. Прихильники опозиційних сил більшою мірою підтримують проведення дострокових виборів, а прихильники політичних сил парламентської коаліції більшою мірою негативно ставляться до цієї ідеї.

Розподіл відповідей на запитання:

Таблиця 6

“Як Ви ставитесь до указів Президента України про розпуск нині діючої Верховної Ради України та проведення дострокових виборів?”, \%

\begin{tabular}{|l|c|c|}
\hline Підтримую & 29,7 & \multirow{2}{*}{42,8} \\
\hline Скоріше, підтримую & 13,1 & \\
\hline Скоріше, не підтримую & 12,4 & \multirow{2}{*}{44,5} \\
\hline Не підтримую & 32,1 & \\
\hline Мене че не чікавить & \multicolumn{2}{|c|}{8,3} \\
\cline { 1 - 2 } Важко відовісти & \multicolumn{2}{|c|}{4,4} \\
\hline
\end{tabular}

Відповідно, регіональні та інші соціально-демографічні особливості підтримки/непідтримки президентських указів виявляються повністю залежними від електоральних преференцій, що детермінують ставлення до цього питання.

$>$ Матеріальне становище та самопочуття населення

о Суб'єктивна оцінка змін соціально-економічного становища країни та власного матеріального становища різних верств населення

Загальний песимізм щодо змін поширюється на більшу частину населення. Хоча $47,8 \%$ респондентів вважають, що суттєвих змін не відбулося, більш ніж третина опитаних зазначають погіршення ситуації. 
Розподіл відповідей на запитання:

“Як Ви особисто оцінюєте зміни соціально-економічної ситуації в країні за останній час?”, \%

\begin{tabular}{|c|c|c|}
\hline За останній час змінилося на краще & 12 & \multirow{2}{*}{ Відбулися позитивні зміни на - 69\% } \\
\hline За останній час суттєвих змін не відбулося & 57 & \\
\hline За останній час погіршилось & 29 & Відбулися негативні зміни на - 26\% \\
\hline Важкко відповісти & 2 & \\
\hline
\end{tabular}

Доволі схожі на попередні і оцінки змін власного економічного становища.

Розподіл відповідей на запитання:

Таблиця 8

“Як змінилося останнім часом економічне становище Вашої родини?”, \%

\begin{tabular}{|c|c|c|}
\hline За останній час змінилося на краще & 12 & 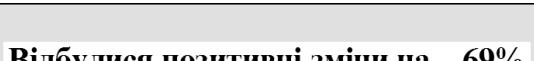 \\
\hline За останній час суттєвих змін не відбулося & 57 & БДДОу.ЛИСЯ ПОЗИТИВН ЗМЫИ НА - \\
\hline За останній час погіршилось & 29 & Відбулися негативні зміни на - 26\% \\
\hline Важкко відповісти & 2 & \\
\hline
\end{tabular}

Частка респондентів, які вважають, що їхнє становище не змінилося, дещо вища за частку тих, хто так само оцінив і зміни в економіці країни в цілому.

\section{$>$ Зовнішньополітичні орієнтації населення}

\section{о Ставлення населення щодо вступу України до НАТО}

Переважна більшість населення продовжує виступати проти вступу до НАТО та орієнтуватися здебільшого на участь у союзі з Росією та Білорусією. Доволі популярною зараз є і думка про те, що необхідно "вибудовувати рівні стосунки з СС та Росією”.

Розподіл відповідей на запитання:

Таблиця 9

“Якби найближчої неділі проводився референдум з питання вступу України до НАТО, як би Ви проголосували?”, \%

\begin{tabular}{|l|c|}
\hline За вступ до НАТО & 19,9 \\
\hline Проти вступу до НАТО & 57,0 \\
\hline Не брав би участі в референдумі (не голосував би) & 12,3 \\
\hline Важско відповісти & 10,9 \\
\hline
\end{tabular}


о Порівняльні оцінки привабливості Свропейського Союзу та союзу з Росією і Білорусією

Розподіл відповідей на запитання: “На Ваш погляд, у якому союзі держав було б краще жити народу України: у Свропейському Союзі чи в союзі з Росією та Білорусією?”, \%

\begin{tabular}{|c|c|c|}
\hline Підтримую & 29,7 & \multirow[b]{2}{*}{42,8} \\
\hline Скоріше, підтримую & 13,1 & \\
\hline Скоріше, не підтримую & 12,4 & \multirow{2}{*}{44,5} \\
\hline Не підтримую & 32,1 & \\
\hline Мене че не цікавить & \multicolumn{2}{|c|}{8,3} \\
\hline Важкко відповісти & \multicolumn{2}{|c|}{4,4} \\
\hline
\end{tabular}

Таблиця 11

Розподіл відповідей на запитання: “Що, на Ваш погляд, є кращим: щоб у керівництві України були політики, які орієнтуються в першу чергу на зближення ...”, \%

\begin{tabular}{|c|c|c|}
\hline За останній час змінилося на краще & 12 & \multirow{2}{*}{ Відбулися позитивні зміни на - 69\% } \\
\hline За останній час суттєвих змін не відбулося & 57 & \\
\hline За останній час погіршилось & 29 & Відбулися негативні зміни на - 26\% \\
\hline Важкко відповісти & 2 & \\
\hline
\end{tabular}

о Мовне питання: оцінки статусу російської мови

Третина населення вважає, що необхідно залишити без змін ситуацію із російською мовою, такою, як вона є зараз, більше чверті вважає, що російській мові необхідно надати статус другої державної, ще майже чверть - зробити російську мову другою офіційною мовою в тих областях, більшість населення яких цього бажає. Лише $12 \%$ опитаних вважають, що необхідно вилучити російську мову з офіційного спілкування по всій Україні.

Таблиця 12

Розподіл відповідей на називання: “Як Ви вважаєте, якою повинна бути державна політика стосовно російської мови в Україні?”, \%

\begin{tabular}{|l|c|}
\hline Статус російської мови потрібно залишити таким, як він є зараз & 33,5 \\
\hline Потрібно зробити російську мову другою державною мовою України & 26,4 \\
\hline $\begin{array}{l}\text { Потрібно зробити російську мову другою офіційною мовою в тих } \\
\text { областях, більшість населення яких цього бажає }\end{array}$ & 24,7 \\
\hline Потрібно вилучити російську мову з офіційного спілкування по всій Україні & 11,7 \\
\hline Інше & 0,3 \\
\hline Важско відповісти & 3,4 \\
\hline
\end{tabular}




\section{$>$ Дострокові вибори:}

\section{о Рівень довіри політичним партіям та об'єднанням}

Відповідно до результатів проведеного дослідження найбільшою довірою населення зараз користуються такі політичні об'єднання: Партія регіонів (довіряють партії 43,3\%), БЮТ (34,0\%), блоки “Наша Україна” (30,6\%) та “Народна самооборона” (29,4\%), Комуністична партія України (25,9\%). Цим політичним силам довіряє понад чверть населення. У решти політичних сил рівень довіри нижчий.

Наведені показники зазвичай інтерпретуються як максимальний вияв підтримки, на який може розраховувати політична сила. Для більш точного розуміння загального сприйняття населенням політичних сил доцільно звернути увагу на баланс тих, хто довіряє і не довіряє. 3 наявного балансу можна побачити, що у всіх без винятку політичних сил частка тих, хто не довіряе, перевищує показники довіри. Найменш “від’ємний” баланс, у порівнянні із іншими, у ПР (- 8,9\%).

\section{Розподіл відповідей на запитання: “Я буду називати партіi,}

Таблиця 13 а Ви скажіть, якою мірою Ви довіряєте ім?”, \%*

\begin{tabular}{|c|c|c|c|c|c|c|}
\hline & $\begin{array}{c}\text { Повністюо } \\
\text { довіряюо }\end{array}$ & $\begin{array}{l}\text { Cкорішіе, } \\
\text { довірsіо }\end{array}$ & \begin{tabular}{|c} 
Скоріше, \\
не довіряно
\end{tabular} & \begin{tabular}{|l}
$\begin{array}{l}\text { 3овсім не } \\
\text { довіряо }\end{array}$ \\
\end{tabular} & $B B^{* *}$ & $\begin{array}{l}\text { Не знаю такої } \\
\text { партії (блоку) }\end{array}$ \\
\hline Партія регіонів & 27,3 & 16,0 & 17,0 & 35,1 & \multirow{2}{*}{3,4} & \multirow[b]{2}{*}{1,2} \\
\hline \multirow{2}{*}{ БЮТ } & \multicolumn{2}{|c|}{43,3} & \multicolumn{2}{|c|}{52,2} & & \\
\hline & \multicolumn{2}{|c|}{34,0} & \multicolumn{2}{|c|}{62,6} & 3,2 & 0,2 \\
\hline Блок «Народна самооборона» & 9,6 & 19,8 & 22,3 & 39,9 & 5,3 & 3,1 \\
\hline \multirow{2}{*}{ Блок «Наша Україна» } & \multicolumn{2}{|c|}{29,4} & \multicolumn{2}{|c|}{62,2} & \multirow[b]{2}{*}{4,6} & \multirow[b]{2}{*}{0,9} \\
\hline & \multicolumn{2}{|c|}{30,6} & \multicolumn{2}{|c|}{63,8} & & \\
\hline \multirow{2}{*}{$\begin{array}{l}\text { Комуністична партія } \\
\text { України }\end{array}$} & 9,0 & 16,9 & 26,1 & 42,2 & \multirow[b]{2}{*}{4,9} & \multirow[b]{2}{*}{0.9} \\
\hline & \multicolumn{2}{|c|}{25,9} & \multicolumn{2}{|c|}{68,3} & & \\
\hline \multirow{2}{*}{$\begin{array}{l}\text { Соціалістична партія } \\
\text { Украйни }\end{array}$} & 5,6 & 17,3 & 26,6 & 43,2 & \multirow[b]{2}{*}{6,6} & \multirow[b]{2}{*}{0,6} \\
\hline & 22 & & &, 9 & & \\
\hline
\end{tabular}

* Наведені дані по партіях та блоках, представлених фракціями у ВРУ.

** Важко відповісти.

\section{о Антирейтинг політичних сил: за які партії та блоки не голосуватимуть}

Проведене дослідження вказує на доволі високий рівень поляризації населення за електоральною ознакою. Фактично, частка тих, хто не буде голосувати за ту чи іншу партію, завжди перевищує показники прихильності до неї. Така ситуація свідчить про те, що більшість виборців керується у своєму виборі тим, що вони проти чогось(когось), і тому голосують за найяскравішого, на їхню думку, опонента. 
Розподіл відповідей на запитання:

“За які з партій Ви б не проголосували в жодному разі?”, \%

(Сума відповідей більше 100\%, тому що респондент міг обрати кілька варіантів відповіді)

\begin{tabular}{|l|c|}
\hline БЮТ & 43,4 \\
\hline Партія регіонів & 32,2 \\
\hline Блок „Напа Україна” & 31,6 \\
\hline Комуністична партія України & 30,8 \\
\hline Прогресивна соціалістична партія України & 22,6 \\
\hline Блок "Народна самооборона" & 22,9 \\
\hline Соціалістична партія України & 24,0 \\
\hline Соціал-демократична партія України (об'сднана) & 19,3 \\
\hline Народний Рух України & 14,2 \\
\hline Партія „Віче” & 11,9 \\
\hline Партія “Реформи і порядок” & 11,6 \\
\hline Українська народна партія & 10,7 \\
\hline Народна партія/Блок „МИ” & 9,8 \\
\hline Партія промисловців та підприемців України & 9,8 \\
\hline Інша партія & 0,1 \\
\hline
\end{tabular}

Найвищій рівень неприйняття зафіксований щодо Блоку Ю. Тимошенко, негативне ставлення до якого притаманне $43 \%$ опитаних. На другому місті у негативному рейтингу - Партія регіонів, частка супротивників якої майже дорівнює чисельності її прихильників.

о Готовність брати участь у дострокових виборах

За більш ніж два місяці до проголошеної дати дострокових виборів майже $80 \%$ опитуваних збирається приходити на виборчі дільниці та голосувати відповідно до зробленого вибору. Отже явку виборців можна прогнозувати на рівні 70-75\%.

Таблиця 15

Розподіл відповідей на запитання: “Якщо восени цього року відбудуться дострокові вибори до Верховної Ради України, чи будете Ви брати в них участь?”, \%

\begin{tabular}{|l|c|c|}
\hline Підтримую & 29,7 & \multirow{2}{*}{42,8} \\
\hline Скоріше, підтримую & 13,1 & \multirow{2}{*}{44,5} \\
\hline Скоріше, не підтримую & 12,4 & \\
\hline Не підтримую & 32,1 & \\
\hline Мене че не иікавить & \multicolumn{2}{|c|}{8,3} \\
\hline Важко відповісти & \multicolumn{2}{|c|}{4,4} \\
\hline
\end{tabular}


$>$ Макропоказники довіри соціальним інституціям та рейтинг основних соціально-економічних проблем

о Рівень довіри соціальним інституціям та органам державної влади

Таблиця 16

Розподіл відповідей на запитання: “Скажіть, будь-ласка, якою мірою Ви довіряєте наведеним нижче організаціям, суспільним інститутам?”, \%

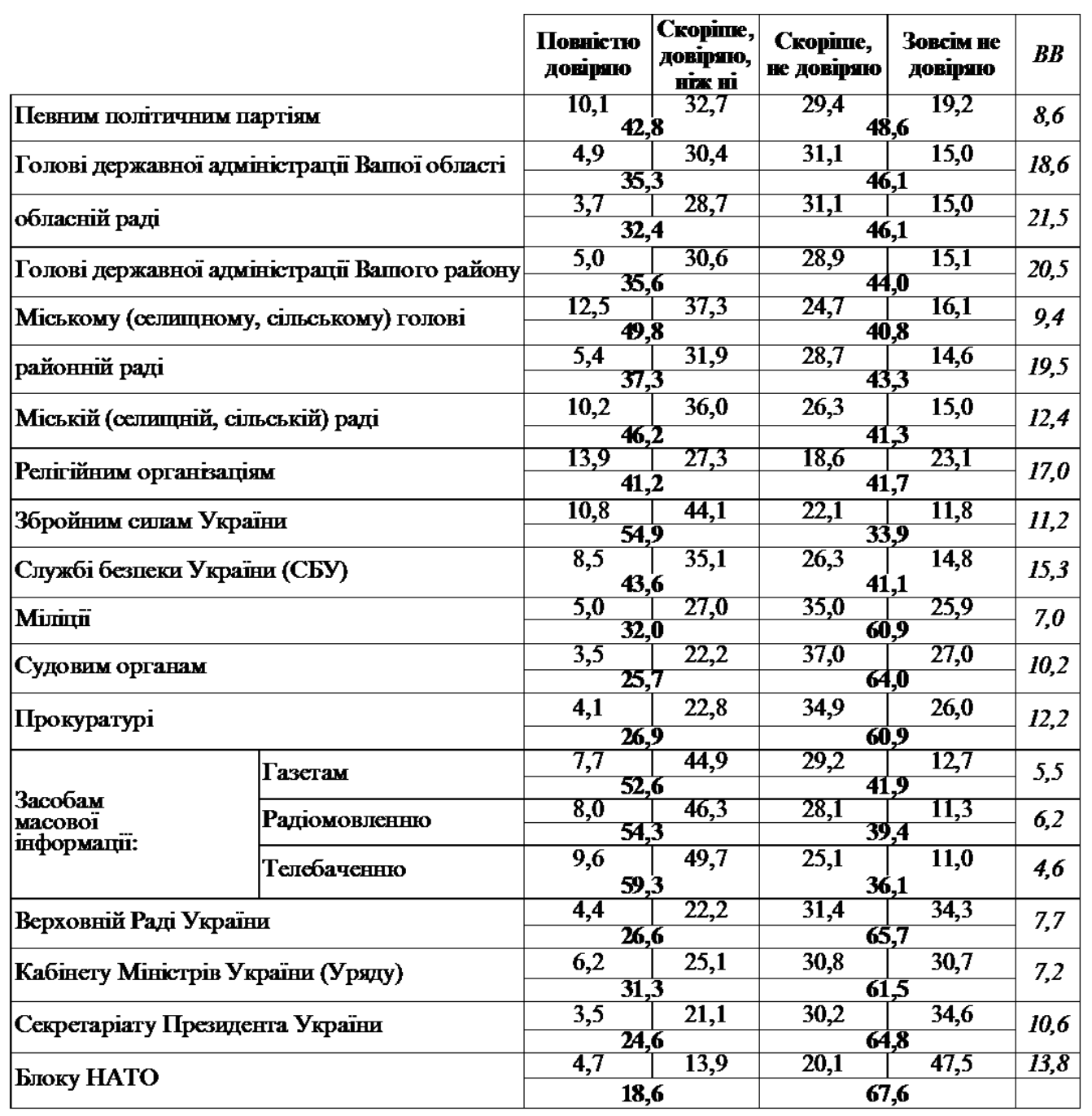


Розподіл відповідей на запитання: “Як Ви оцінюєте діяльність ....?”, \%

\begin{tabular}{|c|c|c|c|c|c|c|c|}
\hline & $\begin{array}{c}\text { Дуже } \\
\text { nогано }\end{array}$ & $\begin{array}{l}\text { Cкopime, } \\
\text { noramo }\end{array}$ & $\begin{array}{l}\text { Hi добре, } \\
\text { ni погано }\end{array}$ & $\begin{array}{l}\text { Cкоріше, } \\
\text { добре }\end{array}$ & $\begin{array}{l}\text { Дуже } \\
\text { добре }\end{array}$ & $\boldsymbol{B B}$ & Баланс \\
\hline \multirow{2}{*}{$\begin{array}{l}\text { Ради національної } \\
\text { безпеки і оборони }\end{array}$} & 7,1 & 18,1 & \multirow{2}{*}{40,2} & 13,7 & 1,1 & \multirow{2}{*}{19,7} & \multirow{2}{*}{$-10,4$} \\
\hline & \multicolumn{2}{|c|}{25,2} & & \multicolumn{2}{|c|}{14,8} & & \\
\hline \multirow{2}{*}{$\begin{array}{l}\text { Генеральної } \\
\text { прокуратури України }\end{array}$} & 13,3 & 26,6 & \multirow{2}{*}{34,3} & 8,2 & 0,8 & \multirow{2}{*}{16,7} & \multirow{2}{*}{$-30,9$} \\
\hline & \multicolumn{2}{|c|}{39,9} & & \multicolumn{2}{|c|}{9} & & \\
\hline \multirow{2}{*}{$\begin{array}{l}\text { Конституційного Суду } \\
\text { Украйни }\end{array}$} & 15,8 & 29,6 & \multirow{2}{*}{31,8} & 7,2 & 0,8 & \multirow{2}{*}{14,9} & \multirow{2}{*}{$-37,4$} \\
\hline & \multicolumn{2}{|c|}{45,4} & & \multicolumn{2}{|c|}{8} & & \\
\hline $\begin{array}{l}\text { Верховного Суду } \\
\text { Украйни }\end{array}$ & 12,9 & 27,1 & 34,9 & 7,9 & 0,8 & 16,4 & $-31,3$ \\
\hline
\end{tabular}

о Які соціально-економічні проблеми потребують скорішого вирішення

Таблиця 18

Розподіл відповідей на запитання:

“Які зі згаданих нижче соціально-економічних проблем повинна, на Вашу думку, першочергово вирішити влада?", \%

(Сума відповідей перевищує 100\%, тому що респондент міг обрати до 4 варіантів відповіді)

\begin{tabular}{|l|c}
\hline Забезпечити доброякісну безплатну медицину & 46,4 \\
\hline Сприяти створенню робочих місць та забезпечити своєчасну виплату заробітної плати & 40,6 \\
\hline $\begin{array}{l}\text { Зупинити зростання цін, розцінок на комунальні платежі та тарифів } \\
\text { на проїзд у транспорті }\end{array}$ & 37,6 \\
\hline Забезпечити підвищення рівня мінімальної пенсії & 33,6 \\
\hline Забезпечити доброякісну безплатну вищу та середню освіту & 25,8 \\
\hline $\begin{array}{l}\text { Забезпечити підвищення рівня заробітної плати в основних галузях } \\
\text { народного господарства }\end{array}$ & 38,1 \\
\hline Забезпечити розвиток сільського господарства & 28,6 \\
\hline Забезпечити стабільні ціни на основні продукти харчування, паливо тощо & 27,2 \\
\hline $\begin{array}{l}\text { Забезпечити подолання бідності шляхом реалізації цільових програм } \\
\text { серед різних соціально незахищених прошарків громадян }\end{array}$ & 20,6 \\
\hline Забезпечити повернення заощаджень & 19,0 \\
\hline $\begin{array}{l}\text { Вирішити екологічні проблеми, забезпечити жорсткий контроль за якістю } \\
\text { продовольчих товарів, питної води тощо }\end{array}$ & 16,3 \\
\hline Зупинити інфляцію, знецінення заощаджень & 15,1 \\
\hline Забезпечити підтримання дрібного та середнього підприємництва & 12,4 \\
\hline Забезпечити проведення справедливої реприватизації & 7,1 \\
\hline Іние & $\mathbf{0 , 6}$ \\
\hline
\end{tabular}

